\title{
LACTASE DEFICIENCY AND THE LACTOSE TOLERANCE TEST
}

Major D. E. BRADFORD, M.B., Ch.B., M.R.C.P.(Edin.), D.T.M. \& H., R.A.M.C.

Captain D. J. LANSDELL-SMITH, M.B., B.S., R.A.M.C.

Sergeant M. HARDY, A.I.M.L.T., R.A.M.C.

British Military Hospital, Dhekelia

LACTASE deficiency in adults is not an uncommon finding and has been reported from North America (Klotz, 1964, Cuatrecasas, Lockwood \& Caldwell, 1965), Switzerland (Auricchio et al, 1963), India (Jeejeebhoy, Desai and Verghese, 1964), Uganda (Cook and Kajubi, 1966), South Africa (Bowie, Barbezat and Hansen, 1967) and the United Kingdom (McMichael, Webb and Dawson, 1966, Ferguson and Maxwell; 1967).

The screening test commonly used for this deficiency is the oral lactose tolerance test, which, although easily performed, has a number of disadvantages. Previous reports (Carson and Neely, 1963, Dahlqvist et al, 1963, Haemmerli et al, 1965, Kern, Struthers and Attwood, 1963, Sheehy and Anderson, 1965) have shown wide variation both in the challenging dose of lactose and in the amount of water used to dissolve the sugar. Tolerance tests indicate the rapidity of absorption rather than the actual amount absorbed (Haemmerli et al, 1965) and blood glucose levels after lactose loading are the resultant of complex factors such as gastric emptying time, absorption, metabolism, storage and excretion of glucose during the test period.

In these circumstances we feel that to be used as an effective screening test for lactase deficiency, the oral lactose tolerance test must be standardised. The aim of this

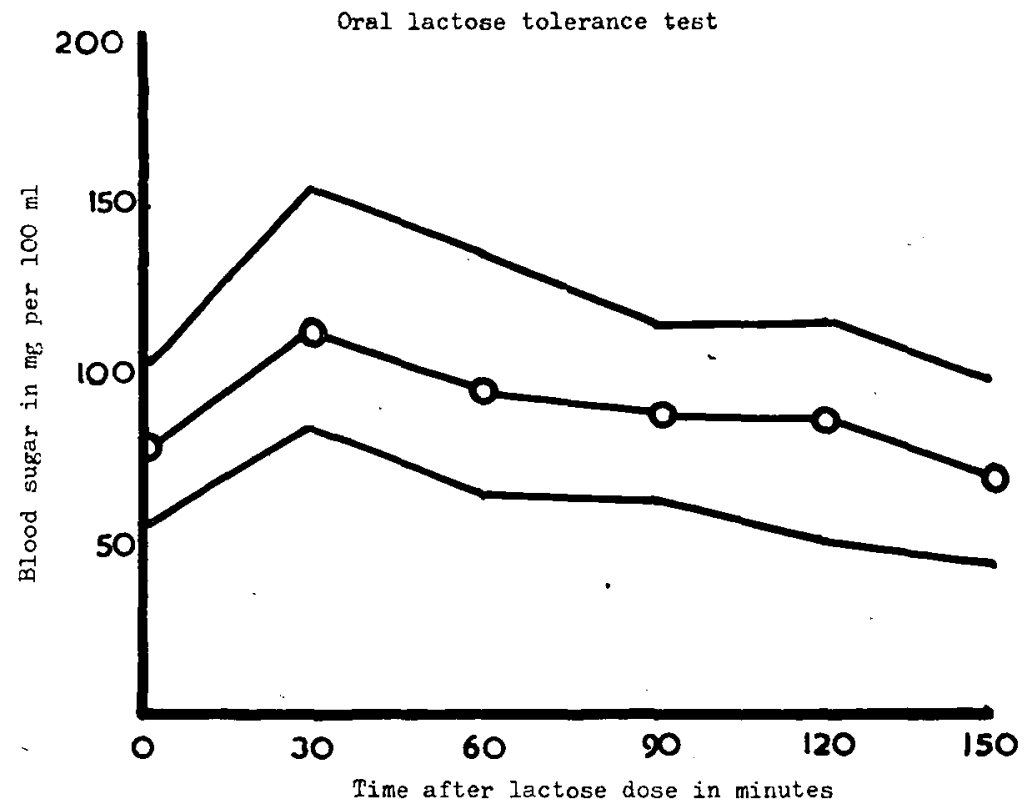

Fig. 1-Mean and range of 10 British subjects 
paper is to describe the test which we have devised, with our reasons for adopting this method, and the results obtained.

\section{Method}

The oral lactose tolerance test is normally carried out by giving an oral dose of $50 \mathrm{~g}$ of lactose dissolved in water. A venous or capillary blood sample is taken from the fasting patient and, following the lactose, further specimens are taken at thirty minute intervals for two and a half hours.

The normal response to lactose loading is a maximum rise in blood sugar of more than $25 \mathrm{mg}$ per $100 \mathrm{ml}$ (Jones, 1964, Haemmerli et al, 1965), although Kern, Struthers and Attwood (1963), Peternel (1965) and Sleisenger (1967) accept a figure of $20 \mathrm{mg}$ per $100 \mathrm{ml}$.

To overcome possible delay in gastric emptying, the lactose can be given via a duodenal tube directly into the small bowel (Kern, Struthers and Attwood, 1963). Thirty grammes of lactose are dissolved in $300 \mathrm{ml}$ of water and run into the duodenum over thirty minutes. Blood samples are taken in the fasting state, at ten-minute intervals for the first hour of the test and at fifteen-minute intervals for a further half hour.

In an attempt to prevent delay in gastric emptying but yet to retain a relatively simple test we have devised the following method:-The initial venous sample is taken from the fasting patient. He is then given $50 \mathrm{~g}$ of lactose dissolved in $500 \mathrm{ml}$ of water and requested to drink this as quickly as possible. He is then given a further $500 \mathrm{ml}$ of water and told to drink this slowly over the ensuing twenty-five to thirty minutes, this being the time available before the second blood specimen is to be taken. Venous blood samples are then taken at 30,60,90,120 and 150 minutes. Blood sugar estimations are made by the method of Asatoor and King (1954) as modified by Sharma and Sur (1966).

This adaption of the lactose tolerance test was carried out on 50 individuals, both convalescent hospital patients and healthy volunteers. Only patients with no known gastro-intestinal disease were included in this series. Of the 50 subjects, 10 were British, 8 Turkish Cypriot, 2 Armenian and 30 Greek Cypriot.

\section{Results}

The results obtained using this oral lactose tolerance test are shown in Figures 1 to 3. It will be seen (Fig 4), that Greek, Turkish, and Armenian Cypriots show a maximum blood sugar rise, after lactose, far smaller than obtained in persons of British origin. In 36 out of 40 (90 per cent) of the Cypriots, this rise was below $20 \mathrm{mg}$ per $100 \mathrm{ml}$.

Diarrhoea during or after the test was associated with a flat sugar curve and occurred in 95 per cent ( 38 out of 40 ) of Cypriots. Diarrhoea did not occur in any of the 10 British.

\section{Discussion}

Following the report of McMichael, Webb and Dawson (1966), who found lactase deficiency in 15 out of 17 Greek Cypriots living in London, we attempted to assess the incidence in Cyprus and our initial results have confirmed their findings.

We selected the oral lactose tolerance test as a relatively simple means of establishing lactose intolerance, but very early in the project discovered that the test commonly 


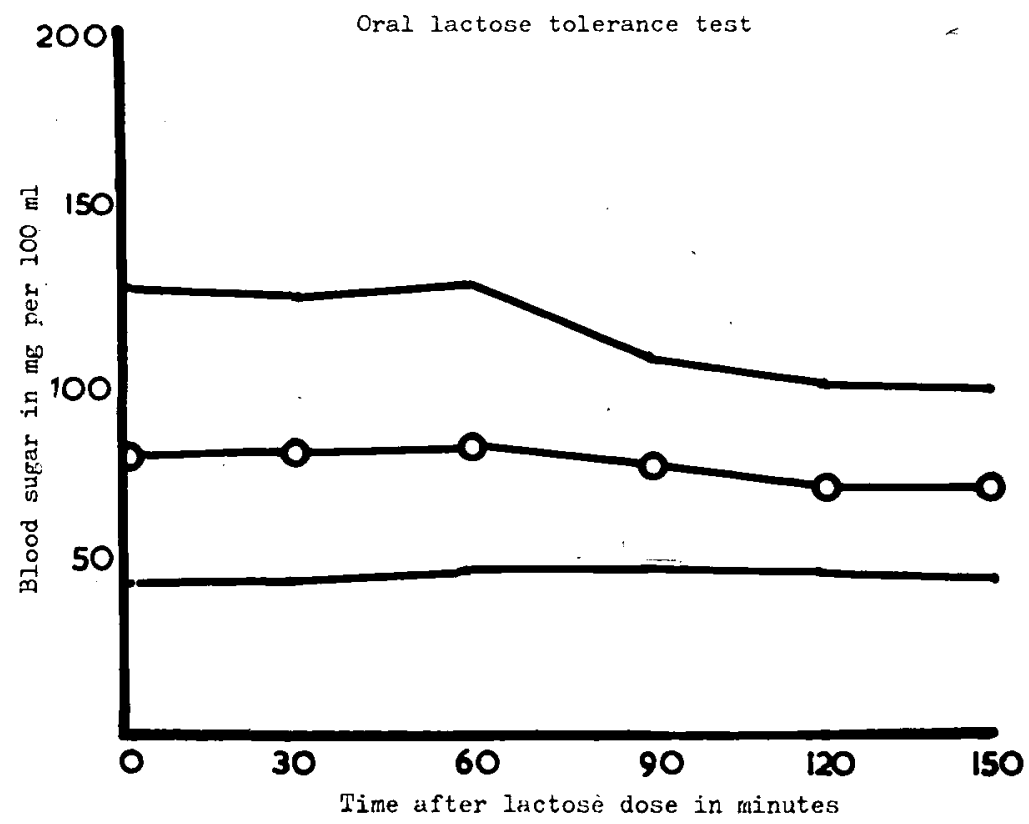

Fig. 2-Mean and range of 30 Greek Cypriots

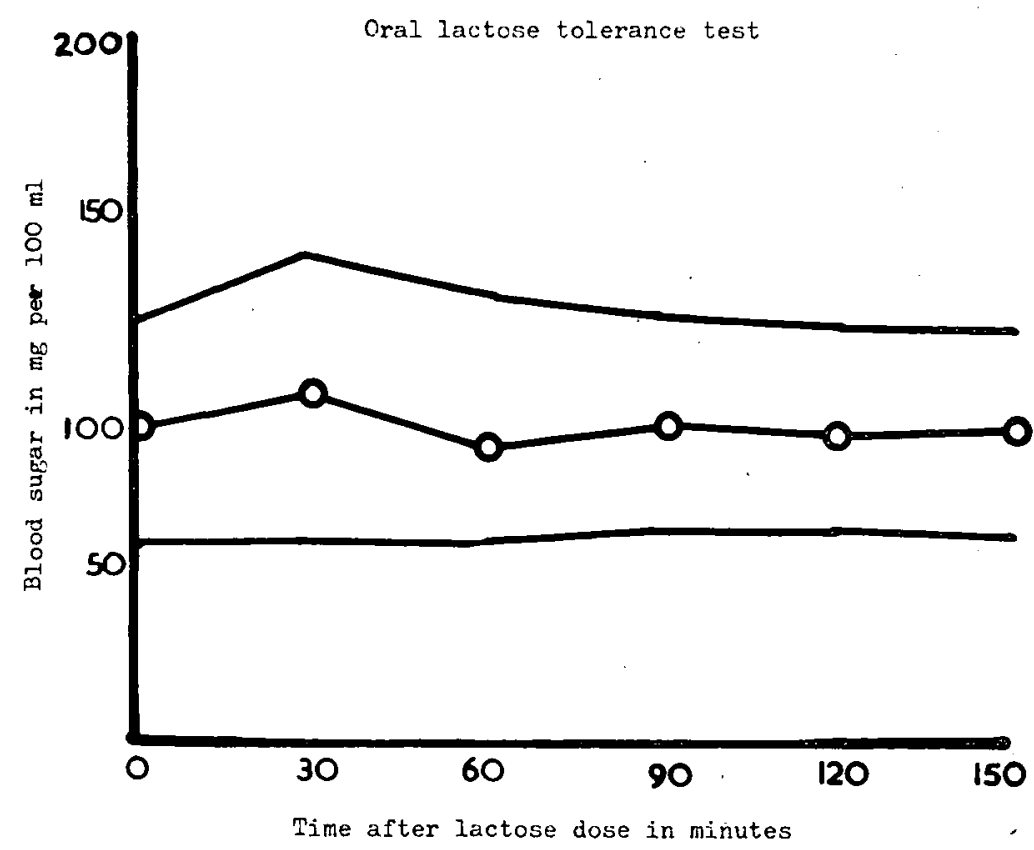

Fig. 3-Mean and range of 10 Turkish/Armenian Cypriots 


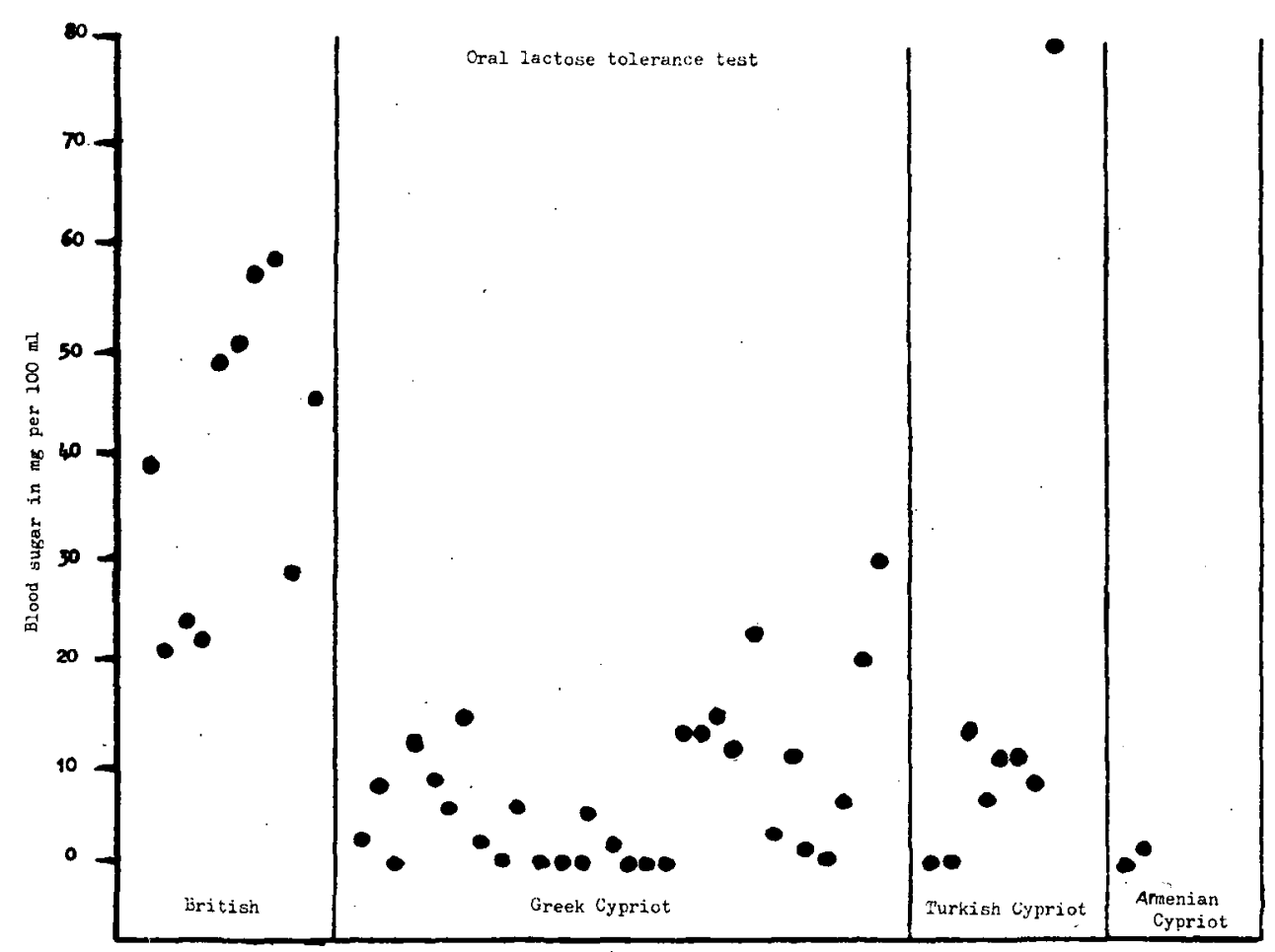

Fig. 4-Maximum blood sugar rise recorded in 50 subjects.

used had the great disadvantage of occasionally producing abnormally flat curves in individuals with normal lactase activity (Durand, 1963). The giving of lactose directly into the duodenum as described by Kern, Struthers and Attwood (1963) is not a method readily adaptable for use in the out-patient department or for studies in large family or racial groups. This method, however, has the advantage of eliminating hold-up of the lactose in the stomach and so reducing the likelihood of an abnormally flat curve in a normal individual.

We feel that increasing the amount of fluid given with the lactose increases the rate of gastric emptying and there is support for this from Hunt (1961) who states that as the concentration of a solute in the gastric content is increased so the volume delivered to the duodenum falls. A loading dose of $50 \mathrm{~g}$ of lactose corresponds approximately to the lactose content of one litre of milk, is the amount used by most workers and seems to us a convenient dose to give to adults. By giving this in a total fluid volume of one litre we not only attempt to overcome delay in gastric emptying, but bring the final concentration of lactose in the stomach close to that of milk.

Lactose occasionally causes nausea and since the rapid intake of one litre of fluid is very likely to aggravate this we have devised the method of giving $50 \mathrm{~g}$ of lactose dissolved in $500 \mathrm{ml}$ of water to be taken quickly, followed by a further $500 \mathrm{ml}$ of water taken slowly over the next twenty-five to thirty minutes. It can be argued that the introduction of a large quantity of fluid into the alimentary tract will not only increase the rate of gastric emptying, but also the speed of passage through the small bowel and that this in itself may produce flat sugar curves and an associated diarrhoea. Against 
this is the fact that no diarrhoea occurred in British subjects undergoing this test.

Haemmerli et al (1965) stress the diagnostic value of the induction of watery acid diarrhoea in lactase deficient individuals after lactose ingestion. It is likely that bacteria in the large bowel break down the lactose to organic acids which induce an osmotic diarrhoea. Using this additional index to assess individuals with equivocal blood sugar curves, we have found that many lactose-intolerant patients develop diarrhoea before the completion of the tolerance test, but we have been unable to correlate either the degree of diarrhoea or the speed of onset with any specific level of blood sugar rise.

We have found only one disadvantage with the adapted oral tolerance test; the results are unreliable in diabetic patients (Haemmerli et al, 1965, Peternel, 1965). In the absence of mucosal lactase estimations we have relied on the associated abdominal pain or diarrhoea following the administration of lactose to indicate lactase deficient individuals. Table I shows the lactose tolerance tests of 4 diabetic patients, two of whom

Table I

Tolerance tests in 4 diabetic patients Blood sugar in $\mathrm{mg}$ per $100 \mathrm{ml}$

\begin{tabular}{|c|c|c|c|c|c|c|}
\hline \multirow[t]{2}{*}{ Case } & \multirow[t]{2}{*}{ Age } & \multirow[t]{2}{*}{ Nationality } & \multicolumn{2}{|c|}{$\begin{array}{l}\text { Lactose tolerance } \\
(50 \mathrm{~g} \text { in } 500 \mathrm{ml}+500 \mathrm{ml} \text { of } \\
\text { water })\end{array}$} & $\begin{array}{l}\text { Glucose tolerance } \\
(50 \mathrm{~g} \text { in } 500 \mathrm{ml})\end{array}$ & \multirow{2}{*}{$\begin{array}{l}\text { Symptoms } \\
\text { after } \\
\text { lactose }\end{array}$} \\
\hline & & & Fasting & $\begin{array}{ccccc}30 & 60 & 90 \quad 120 & 150 \\
\text { min min min min min }\end{array}$ & Fasting $\begin{array}{rrrrr}30 & 60 & 90 & 120 & 150 \\
\text { min min min min } & \text { min }\end{array}$ & \\
\hline A & $60 \mathrm{~F}$ & $\begin{array}{l}\text { Greek } \\
\text { Cypriot }\end{array}$ & 111 & $\begin{array}{lllll}120 & 123 & 138 & 144 & 138\end{array}$ & $\begin{array}{llllll}127 & 210 & 300 & 225 & 165 & 150\end{array}$ & $\begin{array}{l}\text { Abdominal } \\
\text { cramps and } \\
\text { diarrhoea. }\end{array}$ \\
\hline B & $45 \mathrm{~F}$ & $\begin{array}{l}\text { Greek } \\
\text { Cypriot }\end{array}$ & 117 & $\begin{array}{lllll}129 & 141 & 120 & 120 & 120\end{array}$ & $\begin{array}{cccccc}102 & 228 & 180 & 135 & 105 & 120\end{array}$ & Diarrhoea. \\
\hline $\mathrm{C}$ & $38 \mathrm{M}$ & English & 100 & $\begin{array}{lllll}156 & 163 & 150 & 94 & 69\end{array}$ & $\begin{array}{lllll}270 & 335 & 290 & 245 & 210\end{array}$ & None. \\
\hline D & $50 \mathrm{M}$ & English & 106 & $\begin{array}{lllll}222 & 219 & 203 & 175 & 150\end{array}$ & $\begin{array}{llllll}150 & 233 & 233 & 208 & 150 & 122\end{array}$ & None. \\
\hline
\end{tabular}

had diarrhoea following lactose and are therefore considered, by us, to be lactase deficient. Like Peternel (1965) we are unable to draw any conclusion concerning the maximal elevation of blood sugar in diabetic patients with lactase deficiency.

We feel that the dose of lactose for a child should be calculated at $1 \mathrm{~g} / \mathrm{kg}$ body weight, each gramme of lactose being dissolved in or given with $20 \mathrm{ml}$ of water. The figure of $2 \mathrm{~g} / \mathrm{kg}$ (Carson and Neely, 1963, Cook, 1967), is considered excessive in that, for example, a child of six years weighing $20 \mathrm{~kg}$ would require $40 \mathrm{~g}$ of lactose in $800 \mathrm{ml}$ of fluid, a quantity difficult for a child of this age to drink within thirty minutes. A dose of $1 \mathrm{~g} / \mathrm{kg}$ would comprise $20 \mathrm{~g}$ of lactose in $400 \mathrm{ml}$ of water; this reduced volume is more likely to give a successful test.

Cook and Kajubi (1966) have shown that lactase deficiency is common in certain racial groups, while Holzel (1967) has discussed the racial factors involved in adult lactase deficiency. The association of this condition with sprue in India (Jeejeebhoy; Desai and Verghese, 1964) and with protein malnutrition in South Africa (Bowie, Barbezat and Hansen, 1967) may, therefore, be coincidental to a high incidence of lactase deficiency in these areas. Many more studies are required of family and racial 
groups before the true incidence of lactase deficiency on a world scale can be assessed. An oral lactose tolerance test such as we have described, will assist such studies.

\section{Summary}

A modification of the oral lactose tolerance test is described which will enable it to be used in studies of large racial and family groups. The test consists of giving orally $50 \mathrm{~g}$ of lactose in $500 \mathrm{ml}$ of water followed over the next thirty minutes by another $500 \mathrm{ml}$ of water. Blood samples are taken fasting. and at 30,60,90,120 and 150 minutes after lactose. Initial results with this method, which attempts to overcome delay in gastric emptying, have been good. Using this adaptation we have confirmed that lactose intolerance is common among Cypriots.

\section{REFERENCES}

Asatoor, A: M. and KING, E. J. (1954). Biochem. J., 56, 44

Auricchio, S., Rubino, A., Landolt, M., Semenza, G. and Prader, A. (1963). Lancet, ij, 324.

Bowie, M. D., Barbezat, G. O and Hansen, J. D. L. (1967). Amer. J. clin. Nutr., 20, 89

Carson, N. A. J. and Neely, R. A. (1963). Arch. Dis. Childh., 38, 574.

Cook, G. C. (1967). Brit. med.J. i, 527.

CooK, G. C. and KaJUBI, S. K. (1966). Lancet, i, 725.

Cuatrecasas, P., Lockwood, D. H. and Caldwell, J. R. (1965). Lancet, i, 14.

Dahlovist, A., Hammond, J. B., Crane, R. K., Dunphy, J. V. and LitTman, A. (1963). Gastroenterology, 45, 488.

DURAND, R. (1963). Lancet, ii, 841.

Ferguson, A. and MAXWell, J. D. (1967). Lancet, ii, 188.

Haemmerli, U. P., Kistler, H., Ammann, R., Marthaler, T., Semenza, G., Auricchio, S. and Prader, A. (1965). Amer. J. Med., 38, 7.

Holzel, A. (1967). Arch. Dis. Childh., 42, 341

HUNT, J. N. (1961). Gastroenterology, 41, 49.

JeEJeEbHOX, K. N., Desai, H. G. and Verghese, R. V. (1964). Lancet, ii, 666.

JONES, R. H. T. (1964). Lancet, ii, 120.

Kern, F. JR., Struthers, J. E. JR. and ATtwood, W. L. (1963). Gastroenterology, 45, 477.

KLotz, A. P. (1964). Amer. J. dig. Dis.,9, 345.

McMichael, H. B., WebB, J. and Dawson, A. M. (1966). Brit. med. J., ii, 1037.

Peternel, W. W. (1965). Gastroenterology, 48, 299.

Sharma, N. C. and Sur, B. K. (1966). J. clin. Path., 19, 630.

SHEEHY, T. W. and ANDERSON, P. (1965). Lancet, ii, 1.

Sleisenger, M. H. (1967). Cecil-Loeb Text Book of Medicine, 12th Ed., p 894. Saunders, Philadelphia. 